\title{
Analisis Preferensi Penggunaan Moda Kereta Api Bandara Menuju New Yogyakarta International Airport
}

(Analysis of Preference for the Use of Airport Train to New Yogyakarta International Airport)

\author{
DANNY SETIAWAN
}

ABSTRACT

\begin{abstract}
Relocation Adisutjipto Airport to New Yogyakarta International Airport (NYIA) within $\pm 45 \mathrm{~km}$ from Yogyakarta city center by airport train as a liaison transportation modal, it is needed the research of passenger preferences in transportation modal choice analyze to NYIA. Data collection methods used by stated preference (SP) and analyzed by ordered probit model. The results showed ideal distance of air passengers which willing to use the airport train when the airport distance to the city about $37 \mathrm{~km}$. The airplane passenger willingness to pay (WTP) that state "definite use" airport train is about $56.00 \%$ for alternative 8 . The WTP of airport train NYIA is IDR 50.067 with priority level of service is punctuality. The congestion condition from Yogyakarta city to NYIA airport will decrease $46.75 \%$ because the passenger using airport train.
\end{abstract}

Keywords: Stated Preference, Modal Choice, New Yogyakarta International Airport, Airport Train Service

\section{PENDAHULUAN}

Rata-rata peningkatan jumlah penumpang pesawat Bandara Adisutjipto dari tahun 20092015 adalah sebesar 11\%, hal ini menyebabkan Bandara Adisutjipto tidak kondusif lagi untuk dapat menampung penumpang pesawat. Maka diperlukan bandara pengganti yaitu bandara NYIA yang berjarak $\pm 45 \mathrm{~km}$ dari pusat Kota Yogyakarta dan Kereta Api Bandara sebagai moda transportasi penghubung. Didalam mendukung terciptanya moda transportasi Kereta Api Bandara sebagai akses dari/menuju bandara NYIA, diperlukan beberapa kebijakan yang harus diperhatikan dan dipertimbangkan, termasuk diantaranya adalah penentuan tarif yang akan diberlakukan serta fasilitas yang diberikan kepada penumpang.

Penelitian ini bertujuan untuk:

a. Menganalisis preferensi penumpang pesawat dalam memilih moda transportasi menuju bandara.

b. Menganalisis efektivitas penggunaan kereta api bandara.

Manfaat yang diharapkan dari penelitian ini sebagai bahan pertimbangan pembuatan kebijakan pada pelayanan Kereta Api Bandara NYIA. Harapan dari penelitian ini adalah memberikan masukan bagi pemerintah, operator Kereta Api dan pihak terkait lainnya mengenai keinginan dan harapan para penumpang pesawat sebagai calon penumpang Kereta Api Bandara.

Model analisis yang digunakan dalam penelitian ini adalah ordered probit model yang bertujuan untuk mengetahui model respon keinginan penumpang menggunakan layanan kereta api bandara NYIA. Perbedaan dari penelitian yang dilakukan oleh Tamin, dkk (2015) yaitu menggunakan model logit binomial selisih dan logit binomial nisbah, dalam menetapkan tarif kereta api bandara perlu mempertimbangkan kemampuan membayar (Ability to Pay, ATP) dan kesediaan membayar (Willingness to Pay, WTP) calon pengguna (user) kereta api bandara. Penelitian ini menganalisis nilai ATP-WTP menggunakan pendekatan metode analisis pemilihan diskrit (Discrete Choice Analysis) terhadap perilaku individu dengan teknik stated preference (SP). Dimana rentang nilai ATP berada pada probabilitas pemilihan kereta api bandara sebesar 0,5-0,9. Sedangkan nilai WTP berada pada probabilitas pemilihan kereta api bandara sebesar 0,5. Model pemilihan moda yang digunakan adalah model logit-binomial-selisih dan model logit-binomial-nisbah, dengan pemilihan dua moda yang ditinjau adalah 1) Kereta api bandara dan Bus Damri, 2) Kereta 
api bandara dan taksi, 3) Kereta api bandara dan kendaraan pribadi (mobil). Hasil analisis ketiga model pemilihan moda menunjukkan bahwa nilai WTP Bus Damri lebih kecil daripada nilai WTP taksi dan mobil. Sehingga WTP Bus Damri dapat dijadikan batasan tertinggi tarif KA Bandara.

Menurut Profillidis (2006) dan Ischyono dan Miharja (2015), penerapan integrasi kereta api menuju bandara dapat berjalan dengan baik apabila beberapa kondisi di bawah ini dapat terpenuhi, antara lain adalah:

1. Interkoneksi secara fisik antara infrastruktur kereta api dengan bandara, yang berarti pengguna dari stasiun dapat mencapai bandara dengan akses langsung menuju terminal dan dilengkapi fasilitas khusus bagi penyandang cacat.

2. Frekuensi perjalanan kereta api di bandara harus disesuaikan dengan jadwal penerbangan. Untuk memenuhi kebutuhan penumpang, jumlah pemberhentian diusahakan seminimal mungkin namun dapat melayani daerah tangkapan yang besar seperti di daerah pinggiran.

3. Biaya penggunaan kereta api dimasukkan dalam perhitungan tarif perjalanan maskapai sehingga menjadi daya tarik bagi penumpang pesawat.

4. Kontrol keamanan terhadap barang yang dibawa pada saat menggunakan kereta api menuju bandara.

Menurut Joint Transport Research Centre (2008) dan Prasetya dan Muthohar (2012) membahas tentang berbagai faktor yang menentukan pilihan moda transportasi bagi calon penumpang pesawat, di antaranya:

1. Ketersediaan: moda akses yang tersedia, keberadaan kendaraan pribadi; Keberadaan pengantar untuk mengantarkan menuju bandara; Transportasi publik yang tersedia.

2. Waktu akses: waktu tempuh mencapai bandara (termasuk untuk parkir).

3. Biaya Akses: berapa biaya untuk mencapai bandara.

4. Frekuensi (untuk angkutan umum): seberapa sering layanan angkutan umum tersebut tersedia; bagaimana peningkatan waktu tempuh apabila ketinggalan angkutan tersebut.

5. Kenyamanan (untuk angkutan umum): seberapa mudah cara melakukan perjalanan, seberapa sering harus transit, apakah ada jaminan mendapat tempat duduk.
6. Kehandalan: bagaimana kehandalan waktu perjalanan, seberapa handal proses transfernya, berapa waktu yang dipersiapkan agar tidak ketinggalan penerbangan.

Menurut Pearmain dan Kroes (1990), teknik Stated Preference adalah teknik untuk mendapatkan pernyataan yang merupakan respon dari masyarakat atas berbagai alternatif pilihan yang ditawarkan. Penggunaan teknik stated preference dinilai sebagai suatu metode pengumpulan data yang relatif efektif dan efisien. Dalam penelitian ini digunakan model pilihan diskrit (Discrete Choice Models), model analisis ini merupakan model probabilitas yang mana nilai dari masing-masing pilihan responden berkaitan dengan pilihan-pilihan lainnya dalam set alternatif yang ditawarkan, tertera pada Persamaan (1). Dan dianalisis dengan Ordered probit model yang merupakan model berdistribusi normal yang digunakan untuk memprediksi kemungkinan (probabilitas) dari suatu kejadian dengan dependent variable yang bersifat ordinal pada suatu set data discrete choice, tertera pada Persamaan (2). Penentuan ukuran sampel dalam penelitian ini menggunakan formula dari Slovin, tertera pada Persamaan (3). Perhitungan WTP dihitung berdasarkan nilai maksimum rupiah yang bersedia dibayarkan oleh konsumen untuk pelayanan jasa, diolah untuk mendapatkan nilai rata-rata (mean) dari nilai WTP dengan Persamaan (4).

$$
\begin{aligned}
& y^{*}=\beta^{\prime} x+\varepsilon \\
& \mathrm{y}^{*} \quad \text { : dependent variabel dalam bentuk } \\
& \text { ordinal }(0,1,2, . ., \mathrm{n}) \\
& \beta \quad \text { : parameter yang akan dikalibrasi } \\
& \mathrm{x} \quad \text { : independent variabel } \\
& y i:=\beta x+\text { siyi } \\
& y i=0 \text { jika } y i^{*} \leq \mu 0 \\
& y i=1 \text { jika } \mu 0<y i^{*} \leq \mu 1 \\
& y i=2 \text { jika } \mu 1<y i^{*} \leq \mu 2 \\
& y i=j \quad j i k a y i^{*}>\mu j-1 \\
& y i^{*} \quad=\text { nilai variabel independen } \\
& \text { yi }=\text { tingkat prefensi responden dalam } \\
& \text { rangking ordinal }(0-\mathbf{J}) \\
& \mathrm{x} \quad=\text { variabel independen } \\
& \text { gi =utilitas random (random } \\
& \text { utility/random terms) } \\
& \beta=\text { koefisien variabel } \\
& \mu \quad=\text { nilai-nilai yang membatasi variabel } \\
& \text { dependent } y i^{\mu}
\end{aligned}
$$




$$
\begin{aligned}
& n=\frac{N}{1+N e^{2}} \\
& \text { n : Ukuran sampel } \\
& \mathrm{N} \quad \text { : Ukuran populasi } \\
& \text { e : persen kelonggaran ketidaktelitian }
\end{aligned}
$$

\section{METODE PENELITIAN}

\section{Pengumpulan Data}

Data sekunder dalam penelitian ini bersumber dari PT. Angkasa Pura I Yogyakarta atau pihak pengelola Bandar Udara Internasional Adisutjipto dan dari PT. Kereta Api Indonesia atau pihak pengelola Kereta Api Daerah Operasi VI Yogyakarta maupun dari sumbersumber lain. Sedangkan data primer dalam penelitian ini didapatkan melalui teknik Stated Preference (SP). Teknik tersebut dilakukan dengan perpaduan dua metode dasar, yaitu survei kuesioner (questionnaire survey) dan survei wawancara (interview survey) terhadap 400 responden. Jumlah responden didapatkan dari perhitungan sampel menggunakan rumus Solvin, berdasarkan jumlah populasi/penumpang pesawat Bandara
Adisutjipto pada tahun 2015 dengan rata-rata penumpang/hari yaitu sebesar 16066 orang dan tingkat kesalahan sebesar 5\%. Penentuan sampel untuk penelitian ini dilakukan dengan pemilihan sampel secara acak (random sampling) dan pelaksanaan survei dilakukan di terminal keberangkatan atau ruang tunggu domestik Bandara Adisutjipto, penumpang pesawat di ruang tunggu Stasiun Maguwo, terminal bis damri Bandara Adisutjipto, serta masyarakat umum/home interview. Disamping itu peneliti juga melakukan wawancara terhadap pihak penglola/pemangku kebijakan PT. Angkasa Pura I Yogyakarta dan PT. Kereta Api DAOP VI Yogyakarta (tidak termasuk dalam 400 responden) untuk mengetahui kebijakan dalam penentuan tarif kereta api bandara serta asumsi penerapan tarif bagi karyawan.

\section{Penyusunan Atribut}

Berdasarkan pengamatan di lapangan dan studi terdahulu maka diambil lima atribut (tarif, waktu perjalanan, sistem tiketing, frekuensi keberangkatan KA Bandara, dan fasilitas dalam

\begin{tabular}{|c|c|c|c|c|}
\hline Variabel & Atribut & Keterangan & & Level \\
\hline \multirow{10}{*}{$\begin{array}{l}\text { Variable } \\
\text { Independent }\end{array}$} & \multirow{2}{*}{ Tarif } & Rp. 100.000 & Mahal & $0(-)$ \\
\hline & & Rp.75.000 & Murah & $1(+)$ \\
\hline & \multirow{2}{*}{$\begin{array}{l}\text { Waktu } \\
\text { perjalanan }\end{array}$} & 60 menit (berhenti di stasiun antara) & Lama & $0(-)$ \\
\hline & & 45 menit (langsung ke bandara) & Cepat & $1(+)$ \\
\hline & \multirow{2}{*}{ Sistem tiketing } & Tidak terintegrasi dengan layanan pesawat & Tidak integrasi & $0(-)$ \\
\hline & & Terintegrasi dengan layanan pesawat & Integrasi & $1(+)$ \\
\hline & \multirow{2}{*}{$\begin{array}{c}\text { Frekuensi } \\
\text { keberangkatan } \\
\text { KA Bandara }\end{array}$} & Setiap 60 menit & Lama & $0(-)$ \\
\hline & & Setiap 45 menit & Cepat & $1(+)$ \\
\hline & \multirow{2}{*}{$\begin{array}{l}\text { Fasilitas dalam } \\
\text { KA Bandara }\end{array}$} & Bersih, AC, Toilet, Lampu, Bagasi, Tempat duduk & Baik & $0(-)$ \\
\hline & & $\begin{array}{c}\text { Sangat bersih, AC, Toilet, Lampu, Bagasi, Tempat } \\
\text { duduk, Wi-Fi, Tanggungan asuransi }\end{array}$ & Sangat baik & $1(+)$ \\
\hline \multirow{5}{*}{$\begin{array}{l}\text { Dependent } \\
\text { Variable }\end{array}$} & \multirow{5}{*}{$\begin{array}{c}\text { Respon } \\
\text { penumpang }\end{array}$} & Pasti tidak naik & & 0 \\
\hline & & Mungkin tidak naik & & 1 \\
\hline & & Ragu-ragu & & 2 \\
\hline & & Mungkin naik & & 3 \\
\hline & & Pasti naik & & 4 \\
\hline
\end{tabular}
KA Bandara) yang berpengaruh terhadap pemilihan moda dan masing-masing atribut terdiri atas dua level yang mana ke lima atribut tersebut merupakan variable independent. Pada studi ini responden menyatakan pilihannya dengan menggunakan teknik rating, yang dibagi menjadi lima skala ordinal dan merupakan variable dependent. Atribut dapat dilihat pada Tabel 1.

TABEL 1. Atribut kereta api bandara 


\section{Pembuatan Skenario/Alternatif Pilihan}

Dari atribut yang dipilih selanjutnya dibuat beberapa skenario pemilihan terhadap responden. Dengan demikian, bila dikombinasikan seluruh atribut beserta levelnya maka akan diperoleh sebesar 32 skenario/alternatif kombinasi $(2 \times 2 \times 2 \times 2 \times 2$ atau $2^{5}$ ). Kombinasi atribut sebanyak 32 alternatif tentu akan menyulitkan responden dalam memilih. Oleh karena itu kemudian dipilih atau dipecah menjadi bagian yang lebih kecil atau melakukan pembuatan sepertiga replikasi sebagian dari desain faktorial $2^{5}$ melalui proses pembauran (confounding). Dengan mengikuti desain yang disarankan oleh Cochran and Cox (1957) dan Sugiyanto dan Malkhamah (2009), yaitu menggunakan Plan 6A.2, desain kuesioner direncanakan terdiri atas delapan alternatif pilihan seperti yang terdapat pada Tabel 2.

\section{Penentuan Tarif Moda Transportasi}

Dalam penetuan tarif Kereta Api Bandara NYIA dilakukan pendekatan melalui sistem tarif yang terdapat di Bandara Kualanamu, Sumatera Utara. Dimana bandara tersebut telah terintegrasi dengan moda Kereta Api Bandara dan besaran harga Rp. 100.000,- untuk sekali perjalanan dengan jarak $\pm 40 \mathrm{~km}$. Dan penentuan tarif juga ditentukan dari besarnya UMK (Upah Minimum Kota/Kabupaten). Bahwa besar UMK Kota Medan (Gubernur Sumatera Utara, 2014) adalah sebesar Rp. 2.037.000,- sementara UMK Kota Yogyakarta (Gubernur Daerah Istimewa Yogyakarta, 2015) yaitu sebesar Rp. 1.452.400,-, dengan selisih $\pm 25 \%$ maka ditentukan bahwa tarif Kereta Api Bandara NYIA 75\% dari tarif Kereta Api Bandara Kualanamu. Untuk lamanya waktu perjalanan dihitung berdasarkan kecepatan rata- rata kereta api di Indonesia yaitu sebesar 60 $\mathrm{km} / \mathrm{jam}$ berdasarkan (Menteri Perhubungan, 2012) pada PM 60 Tahun 2012. Dengan jarak $\pm 45 \mathrm{~km}$ maka lama waktu tempuh adalah sebesar 0,75 jam atau sekitar 45 menit dengan tipe perjalanan "langsung ke bandara". Untuk tipe perjalanan "berhenti di stasiun antara" maka diasumsikan penambahan waktu sekitar 15 menit. Sehingga waktu tempuh maksimal untuk tipe perjalanan "berhenti di stasiun antara" adalah 60 menit.

Besaran tarif bis damri menuju bandara NYIA ditentukan berdasarkan tarif yang berlaku pada bis damri dari bandara Adisutjipto menuju Magelang/Purworejo dengan besaran tarif sebesar Rp. 50.000,-, dengan pertimbangan jarak yang sama menuju letak bandara baru yaitu di Kulon Progo. Sedangkan besaran tarif taxi menuju bandara NYIA dihitung berdasarkan biaya penumpang mulai dari masuk kedalam taxi Rp. 6.000,- dan biaya jarak per km Rp. 3.200.-, setelah itu dilakukan perhitungan dari jarak pusat kota ke bandara baru Yogyakarta $\pm 45 \mathrm{~km}$ sehingga biaya tarif taxi sebesar Rp. 150.000,-. Serta besaran tarif kendaraan pribadi dihitung berdasarkan kendaraan mobil yang digunakan dengan perbandingan biaya satu liter BBM \pm Rp. $8.000,-\quad$ mampu melayani jarak $\pm 10 \mathrm{~km}$. Selanjutnya dilakuakan perhitungan biaya BBM di kali jarak yang harus ditempuh dari pusat kota ke bandara baru Yogyakarta (pulang-pergi dan parkir) sehingga total tarif kendaraan pribadi sebesar Rp. 100.000,-. Desain kuesioner pemilihan moda transportasi dapat dilihat pada Tabel 3, sehingga responden dapat dengan mudah memilih pilihan moda transportasi apakah yang akan digunakan (kereta api, bus damri, taxi, atau kendaraan pribadi) sebagai akses menuju bandara NYIA dari pusat Kota Yogyakarta.

TABEL 2 Kombinasi perlakuan faktorial $\mathbf{2}^{\mathbf{5}}$ dalam 8 unit

\begin{tabular}{|c|c|c|c|c|c|c|}
\hline \multirow{2}{*}{ Pilihan } & \multirow{2}{*}{$\begin{array}{l}\text { Kombinasi } \\
\text { perlakuan }\end{array}$} & \multicolumn{5}{|c|}{ Perbedaan level atribut } \\
\hline & & travel cost & travel time & ticketing system & headway & facility \\
\hline 1 & $(-)$ & - & - & - & - & - \\
\hline 2 & $\mathrm{AB}$ & + & + & - & - & - \\
\hline 3 & $\mathrm{CD}$ & - & - & + & + & - \\
\hline 4 & ACE & + & - & + & - & + \\
\hline 5 & BCE & - & + & + & - & + \\
\hline 6 & $\mathrm{ADE}$ & + & - & - & + & + \\
\hline 7 & $\mathrm{BDE}$ & - & + & - & + & + \\
\hline 8 & $\mathrm{ABCD}$ & + & + & + & + & - \\
\hline
\end{tabular}


TABEL 3. Pemilihan moda transportasi

\begin{tabular}{|c|c|c|c|c|}
\hline Atribut & Kereta Api & Bus Damri & Taxi & Kendaraan pribadi \\
\hline Tarif & Sesuaidengan & Rp. 50.000,- & Rp. 150.000 & Rp. 100.000 \\
\hline Waktu Perjalanan & pilihan anda & \pm 90 menit & \pm 75 menit & \pm 75 menit \\
\hline Sistem tiketing & pada alternatif & Terintegrasi & Tidak terintegrasi & Tidak terintegrasi \\
\hline $\begin{array}{c}\text { Frekuensi } \\
\text { keberangkatan }\end{array}$ & $\begin{array}{l}\text { di atas (Tabel } 2 \text { ) } \\
\text { yang pasti anda }\end{array}$ & Setiap 30 menit & Flexible & Flexible \\
\hline Fasilitas & akan naik & $\begin{array}{c}\text { AC, Bagasi, Tempat } \\
\text { duduk, Wi-Fi }\end{array}$ & $\begin{array}{c}\text { AC, Bagasi, Tempat } \\
\text { duduk }\end{array}$ & $\begin{array}{c}\text { AC, Bagasi, Tempat } \\
\text { duduk }\end{array}$ \\
\hline
\end{tabular}

TABEL 4. Karakteristik responden

\begin{tabular}{|c|c|c|c|c|c|}
\hline Profil & Kategori & $\%$ Frekuensi & Profil & Kategori & $\%$ Frekuensi \\
\hline \multirow{2}{*}{ Jenis kelamin } & Pria & 61.5 & \multirow{5}{*}{$\begin{array}{l}\text { Penghasilan } \\
\text { (Rp) }\end{array}$} & $<1$ juta & 3.75 \\
\hline & Wanita & 38.5 & & $1-3$ juta & 32.00 \\
\hline \multirow{6}{*}{ Asal } & Yogyakarta & 15.25 & & $3-5$ juta & 32.50 \\
\hline & Sleman & 29 & & $5-7$ juta & 18.25 \\
\hline & Bantul & 12.75 & & $>7$ juta & 13.50 \\
\hline & Kulonprogo & 0.75 & \multirow{6}{*}{$\begin{array}{c}\text { Frekuensi } \\
\text { penggunaan } \\
\text { pesawat }\end{array}$} & $1-2$ kali & 34.5 \\
\hline & Gunung kidul & 0.75 & & 3 - 4 kali & 28.75 \\
\hline & Luar DIY & 41.5 & & 5 - 6 kali & 14.75 \\
\hline \multirow{5}{*}{$\begin{array}{c}\text { Maksud } \\
\text { perjalanan }\end{array}$} & Pendidikan & 13 & & 7 - 8 kali & 6.5 \\
\hline & Pekerjaan & 41 & & 9 - 10 kali & 7.75 \\
\hline & Liburan / Umroh & 17.75 & & $>10$ kali & 7.75 \\
\hline & Urusan keluarga & 21.25 & \multirow{6}{*}{$\begin{array}{l}\text { Biaya 1x } \\
\text { perjalanan } \\
\quad(\mathrm{Rp})\end{array}$} & $<25$ ribu & 33 \\
\hline & Lainnnya & 7 & & $26-50 \mathrm{ribu}$ & 25 \\
\hline \multirow{4}{*}{$\begin{array}{l}\text { Waktu } \\
\text { menuju } \\
\text { bandara }\end{array}$} & $<30$ menit & 28.5 & & $51-75 \mathrm{ribu}$ & 12.25 \\
\hline & $\begin{array}{c}\text { antara } 30-60 \\
\text { menit }\end{array}$ & 48.5 & & 76 - 100 ribu & 19 \\
\hline & $\begin{array}{c}\text { antara } 60-90 \\
\text { menit }\end{array}$ & 12.5 & & $101-150 \mathrm{ribu}$ & 6 \\
\hline & $>90$ menit & 10.5 & & $>150$ ribu & 4.75 \\
\hline
\end{tabular}

\section{HASIL DAN PEMBAHASAN}

\section{Analisis Karakteristik Responden}

Analisis ini bertujuan untuk mengetahui keragaman dari responden penumpang pesawat, berdasarkan data yang diperoleh diketahui memiliki karakteristik seperti pada Tabel 4, pemilihan moda transportasi yang sering digunakan menuju Bandara Adisutjipto tertera pada Tabel 5. Melihat data frekuensi penggunaan moda pesawat dari Tabel 4 dapat diklasifikasikan skala penggunaan seperti pada Gambar 1, diketahui bahwa penumpang pesawat dapat dibagi menjadi dua kategori yaitu daily trip (sering melakukan perjalanan) dan occasional trip (jarang melakukan perjalanan) dalam menggunkan pesawat terbang. Dengan melihat dari frekuensi penumpang dalam menggunakan moda transportasi udara dalam satu tahun, yaitu apabila lebih dari tiga kali dikatakan sebagai kategori daily trip dan apabila kurang dari tiga kali dikatakan sebagai tipe occasional trip. Dengan demikian peneliti melakukan pengurangan jumlah responden yang digunakan sebagai analisis data dengan fokus kepada penumpang pesawat yang memiliki tingkat frekuensi tinggi. Sehingga dari data diperoleh sebesar $65,60 \%$ penumpang yang masuk kedalam kategori daily trip, dan selanjutnya data tersebut digunakan dalam analisis selanjutnya. 


\section{Analisis Persepsi Penumpang Pesawat Terhadap Kinerja Kereta Api Bandara Adisutjipto}

Bandara Adisutjipto merupakan bandara yang telah terintegrasi dengan moda kereta api, tetapi tidak dirancang khusus sebagai moda kereta api bandara bagi penumpang pesawat sebagai akses dari bandara menuju pusat Kota Yogyakarta, kecuali bagi penumpang pesawat yang berasal dari Solo, Klaten, dan Purworejo, karena kereta api Prambanan Ekspres disediakan sebagai akses penumpang Yogyakarta menuju Solo dan rutenya melewati Bandara Adisutjipto sehingga disediakan stasiun pemberhentian pada bada bandara sebagai sarana transportasi bagi penumpang pesawat Bandara Adisutjipto. Dari Tabel 5 dapat dilihat bahwa sebesar $11,75 \%$ penumpang pesawat yang menggunakan kereta api bandara Adisutjipto, kecilnya prosentase ini karena letak bandara yang berada didalam Kota Yogyakarta, yaitu berjarak $\pm 10 \mathrm{~km}$ dan dapat dilihat dari waktu tempuh perjalanan menuju bandara Adisutjipto yaitu $<30$ menit -60 menit sebesar $77 \%$ dari total seluruh responden penumpang pesawat.

Sementara itu jika dilakukan perbandingan terhadap Negara/Kota di Asia yang telah mempunyai kereta api bandara sebagai akses dari pusat Kota menuju bandara yaitu seperti Negara Thailand yang berjarak $\pm 28 \mathrm{~km}$ untuk dapat menuju bandara dari pusat kota, Malaysia berjarak $\pm 57 \mathrm{~km}$, Hongkong berjarak $\pm 35 \mathrm{~km}$, Korea berjarak $\pm 58 \mathrm{~km}$ dan Indonesia pada Kualanamu International Airport - Medan yang berjarak $\pm 40 \mathrm{~km}$ dari pusat kota. Dengan demikian dapat di hitung rata-rata jarak bandara menuju pusat kota dari ke-lima negara tersebut adalah 43,6 km. Sementara dari hasil survei menunjukkan jarak yang ideal bagi penumpang pesawat bersedia menggunakan kereta api bandara NYIA apabila jarak bandara menuju kota Yogyakarta sebesar $37 \mathrm{~km}$ (jarak minimal) data tertera pada Tabel 6, dengan demikian apabila jarak bandara NYIA dari pusat Kota Yogyakarta sebesar $\pm 45 \mathrm{~km}$ maka tingkat efektivitas penggunaan kereta api bandara NYIA dinyatakan layak.

\section{Analisis Preferensi Layanan Kereta Api Bandara}

Hasil analisis preferensi terhadap layanan kereta api bandara NYIA dengan menggunakan skenario pada Tabel 2 didapatkan hasil perilaku pemilihan penggunaan kereta api bandara NYIA yaitu calon penumpang memilih skenario 8 sebesar $56 \%$, secara lengkap tertera pada Tabel 7. Dari analisis dengan menggunakan bantuan software Limdep versi 7.0 (Limited Dependent Variable) yang merupakan alat bantu econometric analysis dengan tingkat signifikasi $95 \%$, hasil pemodelan dapat dilihat pada Tabel 8, dan disusun bentuk persamaan model yang tertera pada Persamaan 5 .

TABEL 5. Pilihan moda transportasi menuju Bandara Adisutjipto

\begin{tabular}{ccc}
\hline Transportasi yang digunakan menuju Bandara & \% Frekuensi & Alasan \\
Adisutjipto & 37,75 & Lebih cepat \\
Kendaraan pribadi & 6,75 & Tarif murah \\
Bis Trans jogja & 11,50 & Lebih cepat \\
Sepeda motor & 11,75 & Lebih murah \\
Kereta api & 21,50 & Lebih aman dan nyaman \\
Taxi & 10,75 & Tidak perlu berpindah angkutan \\
Kendaraan sewa/travel, Fasilitas hotel, Kendaraan & 100 & \\
kantor, Bis umum, dan Bis damri & & \\
\hline Jumlah &
\end{tabular}

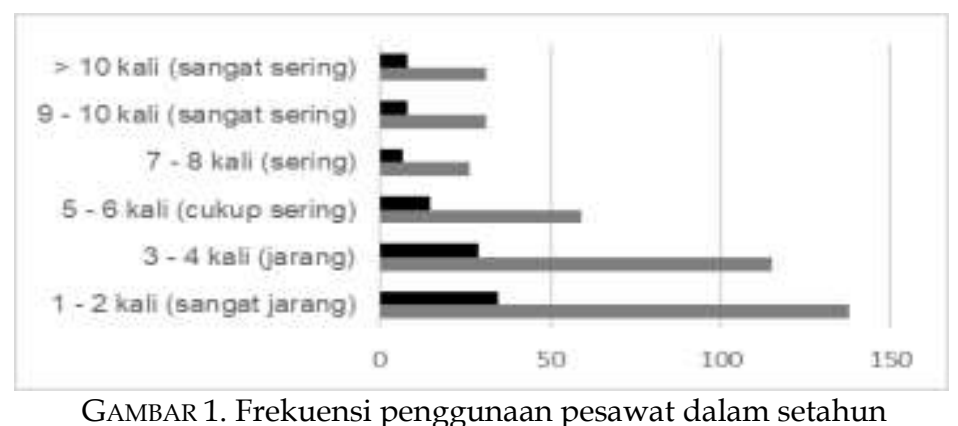

GAMBAR 1. Frekuensi penggunaan pesawat dalam setahun 
TABEL 6. Jarak ideal menuju bandara

\begin{tabular}{cc}
\hline Jarak ideal menuju bandara $(\mathrm{km})$ & \% Frekuensi \\
\hline$<21$ & 7,75 \\
$21-30$ & 22,25 \\
$31-40$ & 35,75 \\
$41-50$ & 24,75 \\
$>50$ & 9,50 \\
\hline Jumlah & $\mathbf{1 0 0}$ \\
\hline Rata-rata & $\mathbf{3 7} \mathbf{~ m m}$ \\
\hline
\end{tabular}

TABEL 7. Perilaku pemilihan moda kereta api bandara NYIA

\begin{tabular}{lcccc}
\hline \multicolumn{1}{c}{ Perilaku } & Alternatif 1 $(\%)$ & Alternatif 2 $(\%)$ & Alternatif 3 $(\%)$ & Alternatif 4 $(\%)$ \\
\hline Pasti tidak naik & 32.25 & 8.75 & 9.25 & 3.50 \\
Mungkin tidak naik & 26.75 & 25.25 & 18.75 & 6.00 \\
Ragu-ragu & 23.75 & 24.75 & 28.00 & 9.00 \\
Mungkin naik & 13.50 & 33.50 & 31.25 & 45.00 \\
Pasti naik & 3.75 & 7.75 & 12.75 & 36.50 \\
\hline \multicolumn{1}{c}{ Perilaku } & Alternatif 5 $(\%)$ & Alternatif $6(\%)$ & Alternatif $7(\%)$ & Alternatif $8(\%)$ \\
\hline Pasti tidak naik & 6.50 & 6.25 & 6.75 & 3.00 \\
Mungkin tidak naik & 13.50 & 12.50 & 17.25 & 3.50 \\
Ragu-ragu & 31.50 & 28.00 & 34.75 & 5.75 \\
Mungkin naik & 28.50 & 42.00 & 33.00 & 31.75 \\
Pasti naik & 20.00 & 11.25 & 8.25 & 56.00 \\
\hline
\end{tabular}

TABEL 8. Hasil pemodelan

\begin{tabular}{|c|c|c|c|c|}
\hline Variabel & Coefisien & Standar Error & $\mathrm{B} / \mathrm{St} / \mathrm{Er}$ (Nilai t) & $\mathrm{P}[\mid \mathrm{Z} />\mathrm{z}]$ (Signifikansi) \\
\hline \multicolumn{5}{|c|}{ Index Function for Probability } \\
\hline Constant & 0.2776135937 & $0.48252300 \mathrm{E}-01$ & 5,753 & 0.0000 \\
\hline Travel cost & 0.7541817188 & $0.38120435 \mathrm{E}-01$ & 19,784 & 0.0000 \\
\hline Travel time & 0.341058497 & $0.37991204 \mathrm{E}-01$ & 8,977 & 0.0000 \\
\hline Ticketing system & 0.7416173782 & $0.38546069 \mathrm{E}-01$ & 19,240 & 0.0000 \\
\hline Headway & 0.287473951 & $0.37868613 \mathrm{E}-01$ & 7,591 & 0.0000 \\
\hline Facility & 0.3006756812 & $0.38178481 \mathrm{E}-01$ & 7,876 & 0.0000 \\
\hline \multicolumn{5}{|c|}{ Threshold Parameters for Index } \\
\hline$\mu 1$ & 0.7129717547 & $0.28892747 \mathrm{E}-01$ & 24,676 & 0.0000 \\
\hline$\mu 2$ & 1.422679963 & $0.34285532 \mathrm{E}-01$ & 41,495 & 0.0000 \\
\hline 43 & 2.515189788 & $0.40817730 \mathrm{E}-01$ & 61,620 & 0.0000 \\
\hline
\end{tabular}

$\mu$

\section{Chi-square}

$\mathrm{y}^{*}=0,277+0,754($ travel cost $)+0,341$ (travel time $)+0,741$ (ticketing system) $+0,287$ (headway) $+0,300$ (facility) ............. (5)

Nilai $\mu 1(0,71), \mu 2(1,42)$ dan $\mu 3 \quad(2,51)$ merupakan parameter model yang membatasi dependent variable. Sedangkan nilai t, signifikan variabel, dan chi-square adalah parameter yang akan digunakan pada proses kalibrasi model.

Untuk:

yi $=0$ (pasti tidak naik)

: jika $y^{*}<0$

yi $=1$ (mungkin tidak naik)

: jika $0<\mathrm{y}^{*} \leq$ 0,71

yi $=2$ (ragu-ragu) yi $=3$ (mungkin naik)

yi $=4$ (pasti naik)

: jika $1,42<\mathrm{y}^{*}$ $\leq 2,51$

: jika $\mathrm{y}^{*}>2,51$

Nilai $y^{*}$ adalah nilai yang didapat saat memasukkan angka-angka untuk variabel tarif, waktu perjalanan, sistem tiket, frekuensi keberangkatan, dan fasilitas, dengan angkaangka yang telah dikuantifikasi dalam nilai "1" jika ada perbaikan/perubahan dan nilai "0" jika tidak ada perubahan dalam hal ini adalah kondisi saat ini. Serta nilai $\mathrm{y}^{*}$ kemudian dimasukkan dalam batas nilai $\mu$ dan selanjutnya didapat nilai yi.

Nilai konstanta sebesar 0,277 menunjukkan bahwa apabila dalam pengoperasian Kereta Api 
Bandara tidak dilakukan peningkatan kualitas pelayanan, maka respon penumpang adalah "mungkin tidak naik". Nilai koefisien untuk tarif sebesar 0,754 maka kesediaan responden menggunakan Kereta Api Bandara adalah sebesar $0,277+0,754=1,031$ artinya "raguragu". Nilai koefisien waktu perjalanan sebesar 0,341 maka kesediaan responden menggunakan Kereta Api Bandara adalah sebesar 0,277 + $0,341=0,618$ yang artinya adalah "mungkin tidak naik". Nilai koefisien untuk sistem tiket sebesar 0,741 maka kesediaan responden menggunakan Kereta Api

Bandara adalah sebesar 0,277 $+0,741=1,018$ yang artinya adalah "ragu-ragu". Nilai koefisien untuk frekuensi keberangkatan kereta api sebesar 0,287 maka kesediaan responden menggunakan Kereta Api Bandara adalah sebesar $0,277+0,287=0,565$ yang artinya adalah "mungkin tidak naik". Nilai koefisien untuk fasilitas dalam kereta api sebesar 0,300 maka kesediaan responden menggunakan Kereta Api Bandara adalah sebesar 0,277 + $0,300=0,577$ yang artinya adalah "mungkin tidak naik".

Dengan menggunakan tingkat signifikasi $95 \%$ $(\alpha=0,05)$ dan derajat kebebasan $(\mathrm{k})$ sebesar 5 maka nilai $X^{2}=11.070$. Untuk model yang dihasilkan, nilai $\mathrm{X}^{2}$ hitung lebih besar dari pada $\mathrm{X}^{2}$ tabel $\left(\mathrm{X}^{2}\right.$ (hitung) $=872.2030>\mathrm{X}^{2}(0,95 ; 5$ $=11.070)$, dan memiliki signifikan $=0,000$ artinya bahwa perbedaan variabel bebas (tarif, waktu perjalanan, sistem tiketing, frekuensi keberangkatan KA Bandara, dan fasilitas dalam KA Bandara) mempunyai pengaruh yang signifikasn terhadap tingkat kemauan penumpang menggunakan kereta api bandara sehingga model yang dihasilkan memiliki rasionalitas yang baik dengan taraf signifikasi $95 \%$.

Pada Tabel 9 menunjukan hasil uji hubungan antar variabel bebas (multikolinearitas) terlihat bahwa nilai dari koefisien variabel bebas tidak ada yang mencapai nilai 1 (satu). Hal ini berarti bahwa antar variabel bebas tersebut tidak mempunyai hubungan yang kuat atau tidak terjadi multikolinearitas, sehingga semua variabel yang ada pada model tersebut dapat digunakan.

Dari Tabel 7 telah diketahui tingkat kemauan membayar penumpang/willingness to pay (WTP) terhadap layanan kereta api bandara, dari hasil pemodelan dapat terlihat bahwa kecenderungan penumpang pesawat menginginkan adanya layanan kereta api bandara, hal ini dapat dilihat dari estimasi bahwa rata-rata penumpang pesawat berkenan menggunakan layanan tersebut. Disamping itu peneliti juga melakukan survei terkait penerapan tarif yang ideal bagi penumpang serta prioritas pelayanan yang diharapkan, dari 262 responden yang termasuk dalam kategori penumpang daily trip (sering melakukan perjalanan) dengan menggunakan Persamaan 4 diketahui WTP minimum responden adalah sebesar Rp. 5.000, dan WTP maksimum responden adalah sebesar Rp. 150.000. WTP rata-rata responden adalah sebesar Rp. 50.067. Dan prioritas pelayanan yang diharapkan adalah ketepatan waktu pelayanan yaitu sebesar $33,21 \%$, dapat dilihat pada Gambar 2 dan Gambar 3. Serta dilakukan wawancara terhadap pemangku kebijakan dalam hal ini adalah PT. Angkasa Pura I Yogyakarta dan PT. Kereta Api DAOP VI Yogyakarta terkait sistem tarif pada karyawan, dihasilkan bahwa pihak terkait masih belum mendapatkan jawaban pasti dikarenakan proyek bandara NYIA yang masih akan diselesaikan sampai dengan 4 tahun kedepan dari sekarang (Tahun 2016) atau dapat mengacu pada Keputusan Direksi PT. Kereta Api Indonesia (Persero) Nomor: KEP.U/LL/003/XI/1/KA-2015 Tentang SyaratSyarat Dan Tarif Angkutan Kereta Api Penumpang, tarif reduksi terhadap pegawai perusahaan sebesar $50 \%-75 \%$ dengan ketentuan masing-masing.

TABEL 9. Koefisien korelasi antar variabel bebas

\begin{tabular}{|c|c|c|c|c|c|}
\hline Variabel bebas & Tarif & Waktu perjalanan & Sistem tiketing & Frekuensi & Fasilitas \\
\hline Tarif & 1 & 0 & 0 & 0 & 0 \\
\hline Waktu perjalanan & 0 & 1 & 0 & 0 & 0 \\
\hline Sistem tiketing & 0 & 0 & 1 & 0 & 0 \\
\hline Frekuensi & 0 & 0 & 0 & 1 & 0 \\
\hline Fasilitas & 0 & 0 & 0 & 0 & 1 \\
\hline
\end{tabular}




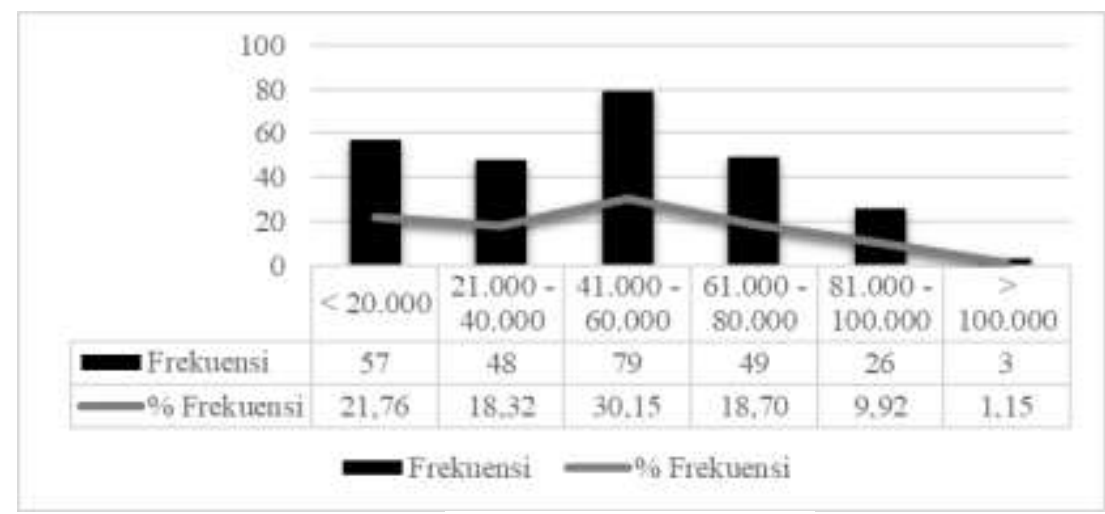

GAMBAR 2. Diagram WTP responden

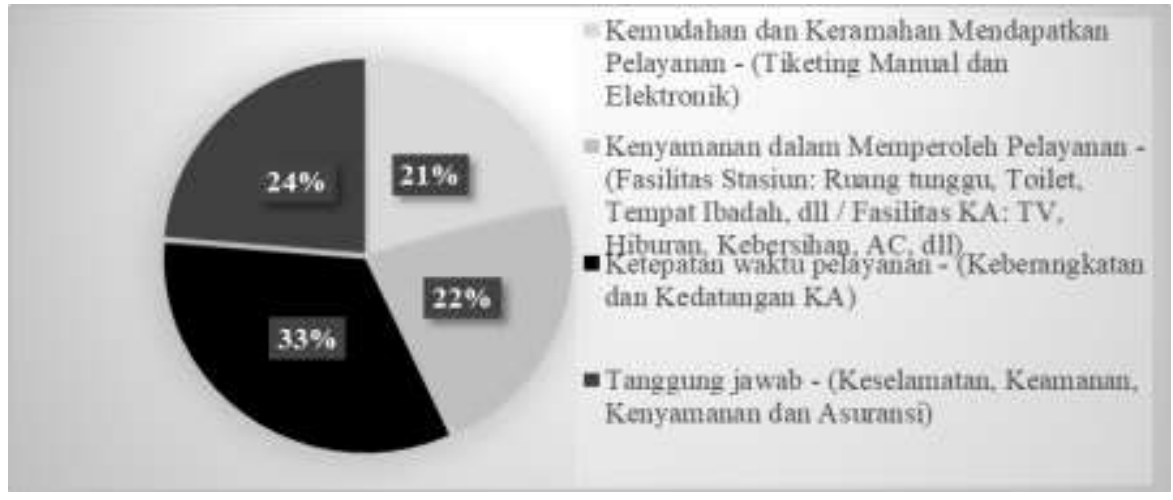

GAMBAR 3. Diagram prioritas pelayanan Kereta Api Bandara

TABEL 10. Hasil pemilihan moda transportasi lanjutan penumpang pesawat

\begin{tabular}{|c|c|c|}
\hline Pemilihan moda transportasi & Frekuensi & $\%$ Frekuensi \\
\hline Kereta api bandara & 187 & 46.75 \\
\hline Bis Damri & 78 & 19.5 \\
\hline Taxi & 41 & 10.25 \\
\hline Kendaraan pribadi & 94 & 23.5 \\
\hline Jumlah & 400 & 100 \\
\hline
\end{tabular}

\section{Analisis Pemilihan Moda Transportasi}

Setelah diketahui preferensi penumpang pesawat terhadap kereta api bandara, selanjutnya dilakukan survei kembali terhadap penentuan moda transportasi apakah yang akan dipilih oleh penumpang dalam akses dari/menuju New Yogyakarta International Airport dengan pilihan moda transportasi adalah kereta api bandara, bus damri, taxi, dan kendaraan pribadi. Dengan asumsi semua pelayanan transportasi umum sudah terjadi peningkatan pelayanan secara maksimal pada tarif, waktu perjalanan, sistem tiketing, frekuensi keberangkatan, dan fasilitas seperti pada Tabel 3, sehingga responden hanya memilih diantara empat moda transportasi yang ditawarkan dan selanjutnya dihitung berapa prosentase pemilihan modanya, hasilnya disajikan pada Tabel 10 .

\section{KESIMPULAN}

1. Efektivitas kereta api bandara NYIA ditinjau dari segi jarak dinyatakan layak karena penumpang pesawat bersedia menggunakan kereta api bandara NYIA sebagai moda transportasi penghubung, dengan jarak ideal adalah minimal sebesar $37 \mathrm{~km}$.

2. Penumpang pesawat menginginkan pelayanan sebagaimana skenario yang ditawarkan responden/alternatif 8 yaitu tarif Rp.75.000,-, waktu perjalanan yang cepat yaitu 45 menit (langsung menuju 
bandara), dengan sistem tiket yang terintegrasi dengan layanan pesawat, dan frekuensi keberangkatan setiap 45 menit, serta dengan fasilitas kereta api "Baik". Dan respon penumpang adalah "Pasti Naik" yaitu sebesar $56,00 \%$, dan model yang dihasilkan memiliki rasionalitas yang baik dengan taraf signifikasi $95 \%$.

3. Penumpang pesawat memilih menggunaakn moda Kereta Api Bandara sebagai akses dari pusat Kota Yogyakarta menuju bandara NYIA yaitu sebesar 46,75\%. Hal ini dikarenakan penumpang pesawat menginginkan kepastian waktu perjalanan dan memberikan dampak pada pengurangan kemacetan lalu lintas.

\section{DAFTAR PUSTAKA}

Cochran, W. G. and Cox, G. M., 1957. Experimental Design, John Wiley \& Sons Ltd, New York.

Gubernur Daerah Istimewa Yogyakarta, 2015. Upah Minimum Kabupaten/Kota Tahun 2016 Di Daerah Istimewa Yogyakarta, Keputusan Gubernur Daerah Istimewa Yogyakarta Nomor 255/KEP/2015, Daerah Istimewa Yogyakarta.

Gubernur Sumatera Utara, 2014. Penetapan Upah Minimum Kota Tahun 2015, Keputusan Gubernur Sumatera Utara Nomor 188.44/1055/KPTS/Tahun 2014, Medan.

Iscahyono, A. F. dan Miharja, M., 2015. Analisis Peluang Pemilihan Moda Mobil Pribadi dan Kereta Api Sebagai Moda Transportasi Menuju Bandara (Studi Kasus: Bandara Baru di Kulonprogo, DIY), Jurnal Perencanaan Wilayah dan Kota A SAPPK V4N1, Institut Teknologi Bandung, Bandung.

Joint Transport Research Centre, 2008. The Role of Accessibility in Passengers' Choice of Airports. International Transport Forum. No. 2008-14.

Kereta Api Indonesia (Persero), PT, DAOP VI, 2016. Syarat-Syarat Dan Tarif Angkutan Kereta Api Penumpang, Keputusan Direksi PT. Kereta Api
Indonesia (Persero) Nomor: KEP.U/LL/003/XI/1/LA-2015, Bandung.

Menteri Perhubungan, 2012. Persyaratan Teknis Jalur Kereta Api, Peraturan Menteri Perhubungan PM 60 Tahun 2012, Jakarta.

Prasetya, Y. dan Muthohar, I., 2012. Analisis Penerapan Integrasi Kereta-Pesawat Di Bandara Adisutjipto Yogyakarta, Jurnal Forum Studi Transportasi Antar Perguruan Tinggi, Teknik Sipil dan Lingkungan, Universitas Gadjah Mada, Yogyakarta.

Pearmain, A. D. and Kroes, E., 1990. Stated Preference Techniques a Guide to Practice, Steer Davies \& Gleave Ltd, Netherlands.

Profillidis, V. A., 2006. Railway Management and Engineering, Cetakan ke-3, Burlington: Ashgate Publishing Company.

Sugiyanto, G. dan Malkhamah, S., 2009. Model Pemilihan Moda Antar Mobil Pribadi Dan Bis Trans Jogja Akibat Penerapan Biaya Kemacetan, Jurnal Transportasi Vol. 9 No. 2 Desember 2009: 97-106, Universitas Gadjah Mada, Yogyakarta.

Tamin, O. Z., Wulansari, D. N., Wibowo, S. S., dan Weningtyas, W., 2015. Analisis Ability to Pay (ATP) Dan Willingness to Pay (WTP) Pengguna Kereta Api Bandara (Studi Kasus: Bandar Udara Internasional Soekarno-Hatta), Jurnal Forum Studi Transportasi Antar Perguruan Tinggi, Program Studi Magister Teknik Sipil, Institut Teknologi Bandung, Bandung.

PENULIS:

\section{Danny Setiawan}

Program Studi Teknik Sipil, Fakultas Sains dan Teknologi, Universitas Teknologi Yogyakarta, Jalan Glagahsari No. 63, Kampus 2 UTY, Yogyakarta.

Email: danny.setiawan@staff.uty.ac.id 